\title{
The role of intermediate
} inputs in a multisectoral

\section{balance-of-payments-constrained growth model: the case of Mexico}

\author{
Ricardo Azevedo Araujo ${ }^{1 *} \mathbb{D}$, Matheus Silva de Paiva ${ }^{2}$ and Júlio Fernando Costa Santos ${ }^{3}$
}

\section{${ }^{*}$ Correspondence:}

rsaaraujo@unb.br

${ }^{1}$ Department of Economics, University of Brasilia, Campus Universitário Darcy Ribeiro, Brasília, DF 70910-900, Brazil

Full list of author information is available at the end of the article

\begin{abstract}
We focus on the effects of the imports of intermediate inputs over the growth performance. Such an analysis is essential insofar as some countries import large amounts of intermediate inputs to be used in the production of final goods to export. Then it arises the question of whether such a strategy is harmful to the growth performance in a balance-of-payments-constrained growth (BPCG) setup. To address this point, the paper blends the multisectoral BPCG model incorporating structural change (MSTL), by Araujo and Lima (Camb J Econ 31(5):755-774, 2007), and the BPCG model including intermediate goods by Blecker and Ibarra (Struct Change Econ Dyn 25(C):33-47, 2013), and applies the resulting framework to the Mexican economy from 1962 to 2014. The most important result is that the MSTL growth rate in the presence of foreign content of exports is lower than the 'standard' MSTL growth rate calculated in the usual fashion (ignoring intermediate imports). That shows the importance of considering imports of intermediate goods in a BPCG model, at least for countries such as Mexico that rely massively on them. It especially helps to explain the reduction both in the ratio of the income elasticities and the growth rate of the Mexican economy, a result also found by Ibarra (Econ Change Restruct 44:357-368, 2011).
\end{abstract}

Keywords: Intermediate inputs, Balance-of-payments-constrained growth, Structural change, Mexico

\section{Introduction}

The role of imports of intermediate inputs as one of the elements of a sound growth strategy is a contentious issue. For some authors, see, e.g., Amiti and Konings (2007), and Goldberg et al. (2010), the access to imported intermediate goods allows for quality improvement in manufacturing products and broader participation of a country in international trade. Their viewpoint rests on the arguments that the increased availability of imported inputs may facilitate product diversification and trigger pro-competition effects, inducing cost reductions and quality improvements in the final product. But for other authors such as Blecker and Ibarra (2013), Moreno-Brid $(1999,2002)$ and PachecoLópez and Thirlwall (2004) the reliance on a strategy based on foreign content of export may be harmful to growth. While for Moreno-Brid $(1999,2002)$ and Pacheco-López 
and Thirlwall (2004) such strategy may result in an increase in the income elasticity of demand for imports without a compensating effect on the income elasticity of exports, Blecker and Ibarra (2013) have argued that it may lead to a shift in the composition of imports (i.e., structural change) toward a higher share of intermediate goods. If this is the case, then a country that relies on imports of intermediate input may experience lower growth rates consistent with balance-of-payments (BoP) equilibrium. This kind of reasoning follows straight from the balance-of-payments-constrained growth (BPCG) hypothesis, which considers that a country long-run growth rate can be approximated by the ratio of the export and import income elasticities multiplied by the growth rate of foreign income (see Thirlwall 1979; Perraton 2003). ${ }^{1}$

To assess a strategy based on imports of intermediate goods, we follow two contributions to the disaggregated view of the BPCG hypothesis. The first is the multisectoral Thirlwall's law-MSTL hereafter-advanced by Araujo and Lima (2007). According to that view, the export and import elasticities may be considered as an averaged mean of sectoral export and import elasticities, respectively, being the weight of each sectoral elasticity the share of each sector in trade. With such derivation, the authors have shown that even if sectoral elasticities and world income growth are constant, a country can grow faster by either increasing the share in exports of sectors with a high-income elasticity for exports or decreasing the share in imports of sectors with a high-income elasticity for imports. Such range of view, which points to the connections between economic growth and structural change, has been confirmed by studies showing that countries that relied upon strategies based on export-led structural changes such as the East Asian countries succeeded in catching up (see, e.g., McMillan and Rodrik 2011). ${ }^{2}$

The second approach is due to Blecker and Ibarra (2013) whose contribution aims to give more realism to the BPCG hypothesis by considering explicitly the imports of intermediate goods. The authors found that while an increase in foreign content of exports may enhance the growth of manufactured exports, they affect negatively the rate of output growth consistent with BoP equilibrium. But the final answer, namely if the strategy is beneficial or not to growth, is an empirical question that has to be addressed 'with a model that adequately incorporates the key role of intermediate imports in relation to the country's manufactured exports' (see Blecker and Ibarra 2013, p. 37). To carry out their analysis, they have considered two types of exports (manufactured and primary commodities) and two types of imports (intermediate and final goods). Notwithstanding providing a pioneering contribution in this matter, they have made some stringent assumptions, namely: (1) fixed number of sectors, with the export structure considering just two kinds of sectors, namely manufactured and primary commodities, (2) imports

\footnotetext{
${ }^{1}$ The Thirlwall's law (Thirlwall 1979), as this hypothesis is known, is an empirical regularity that has been confirmed for a number of countries (see, e.g., Thirlwall 2012; Razmi 2005; Jeon 2009; McGregor and Swales 1985; Atesoglu 1993; Halicioglu 2012).

2 Following the derivation of the MSTL number of empirical studies aiming at testing it has found support to the disaggregate version (see, e.g., Gouvea and Lima 2010, 2013; Tharnpanich and McCombie 2013; Romero and McCombie 2016). These papers highlight the fact that higher levels of disaggregation allow us to better understand the factors that can spur growth mainly in underdeveloped and in emerging countries. In all cases, the authors have found that export and import composition plays an important role in explaining growth experiences, with high and sustained growth rates being related to a larger share of high-tech products in exports. Countries that increase the share of high-tech goods in their exports benefit more from international trade than those that specialize in the production and exports of goods with low-income elasticity.
} 
and import-competing domestic goods having the same price, and (3) the growth rate of exports of the primary goods and their price growing at an exogenously given rate.

A common thread of these two contributions, namely Blecker and Ibarra (2013) and Araujo and Lima (2007), is the acknowledgment that any strategy that affects the structure of the economy may have an impact on the growth performance. To go a step further in establishing connections between these approaches, we intend to extend the Blecker and Ibarra (2013) analysis by relaxing some of their hypothesis in accordance with the derivation of the MSTL. Such derivation becomes essential insofar as, over the last 2 decades, the production pattern has shifted toward the split of production stages among several producers accompanied by increased trade in intermediaries. Here following the Araujo and Lima (2007) approach, we present a fully multisectoral version of the BPCG model in the presence of intermediate inputs. ${ }^{3}$ The main result that accrues from this derivation is that the BPCG rate is lower in the presence of foreign content of exports.

In order to check the robustness of this result from an empirical viewpoint, we have focused on the Mexican economy pre- and post-liberalization period and have compared the estimates obtained from the original MSTL with the one derived here considering foreign content of exports. To estimate sectoral elasticities, we have adopted the log versions of the series in level (see Gouvea and Lima 2010) with data from COMTRADE, which allows us to test the extended model considering six export and import sectors. We employed the Johansen methodology that allows us to consider cointegration of I(1) series (see, e.g. Johansen and Juselius 1990; Moreno-Brid 1999; Blecker and Ibarra 2013) to check whether the new version of the MSTL with intermediate inputs has a better predictive power than the original MSTL. The econometric results show that the former presents a slightly better fit than the latter when the case of Mexico is under consideration.

Besides, by using estimates from the MSTL with intermediate goods we explain the decay in the ratio of export to import income elasticities that took place after trade liberalization, a result reported by some authors such as Moreno-Brid $(1999,2002)$ and Pacheco-López and Thirlwall (2004). But, to evaluate properly the differences between the two versions, we have also run numerical simulations by using the estimated elasticities to compare the performance of the economy in the long run. While the econometric estimates do not differ substantially, numerical simulations allowed us to conclude that not considering foreign content of exports can lead us to overestimate the BPCG growth rate, which can give rise to relevant distortions in the long run.

The analysis presented here shows that a multisectoral analysis yields a more inclusive approach to the role of building a growth strategy based on foreign content of exports. If, on the one hand, such a strategy allows manufacturers to benefit from having access to varied and good quality intermediate inputs, on the other hand, it lessens the gains from increased exports, potentially leading to a tightening rather than a loosening of the BoP constraint,

\footnotetext{
${ }^{3}$ We follow Blecker and Ibarra (2013) by assuming that the growth rate of intermediate inputs is a function of the growth rate of exports. But here we intend to proceed to a higher level of disaggregation. While Blecker and Ibarra (2013) have considered just four sectors, namely two exporters and two importers, the version presented here is advanced in a fully multi-sectoral scheme, which considers an arbitrary number of sectors. We have also dropped assumptions (2) and (3).
} 
mainly if the intermediate inputs present high elasticity with respect to exports. The outcome, namely if such a strategy is beneficial or harmful to growth, is a question addressed in this paper analytically and empirically concerning the Mexican economy. Besides this introductory section, this article comprises three more sections. The next one advances a derivation of an MSTL with intermediate inputs, and Sect. 3 presents the econometric and numerical simulation exercises comparing the original MSTL (Araujo and Lima 2007) and the one derived here. Section 4 concludes.

\section{Derivation of the multisectoral Thirlwall law with intermediate inputs}

The fact that Mexican exports are highly dependent on foreign content of exports has been highlighted by some authors as Moreno-Brid et al. (2005) and Ibarra and Blecker (2016). One of the striking aspects of this arrangement is that the exports of final goods require massive imports of intermediate goods, giving rise to the question of whether such a strategy is harmful to growth under a BoP constraint. To address this question, a proper analytical framework is a disaggregated version of Thirlwall's law (Thirlwall 1979) such as the one advanced by Araujo and Lima (2007) due to its focus on the multisectoral assessment of the BPGC hypothesis. Notwithstanding the BPCG model has implicitly considered the role of the structure, it was not originally designed for analyzing the impacts of a strategy based on imports of intermediate goods insofar as it considers only the exports and imports of final goods (see Thirlwall 1979). Conscious of such limitation, Blecker and Ibarra (2013) have explicitly introduced the possibility of importing intermediate goods in a BoP framework with four sectors, two exporters, namely manufactured exports and primary commodities, and two importers, namely intermediate and final goods. By considering the growth rate of imports of intermediate goods as a function of the growth rate of exports of manufactures, the authors have found a reduction in the BoP equilibrium growth rate from an analytical viewpoint. More specifically, they have found that the income elasticity of imports of intermediate goods generates a decrease in the income elasticity of exports of final goods.

In what follows, we derive a multisectoral version of the MSTL in the same spirit of Blecker and Ibarra (2013) but now with an arbitrary number of sectors. To accomplish that, we consider the existence of two countries namely $D$ (domestic) and $F$ (foreign) (see Nishi 2016) and carry out the analysis from the viewpoint of domestic country. To keep the analysis consistent with the Structural Economic Dynamic (SED) approach (see, e.g., Pasinetti 1993), from which the MSTL was initially derived we assume that there are $n$ sectors in the economy, being $n-1$ sectors responsible for producing final consumption goods, while the $n$th sector is the household sector (see Pasinetti 1981, p. 30), which is responsible for endow the remaining $n-1$ sectors with labor. We specify sectoral import functions of intermediate goods according to Blecker and Ibarra (2013): the demand for intermediate inputs in terms of one unit of final output of the $i$ th good for exports, namely $m_{k_{i}}$, is a function of the income of the domestic country $Y_{D}$, weighted by the income elasticity of demand $\eta_{D k_{i}} \geq 0$, and export demand for good $i, x_{i}$, weighted by the export demand income elasticity of good $i, \gamma_{D k_{i}} \geq 0$. We also consider that price competitiveness plays a role, which allows us to write the sectoral demand for the intermediate input as:

$$
m_{k_{i}}=\bar{m}_{k_{i}}\left(\frac{e p_{F k_{i}}}{p_{k_{i}}}\right)^{-\varepsilon_{D k_{i}}} Y_{D}^{\eta_{D k_{i}}} x_{i}^{\gamma_{D k_{i}}}
$$


where $\bar{m}_{k_{i}}$ is a constant terms, $e$ stands for the nominal exchange rate, $e p_{F k_{i}}$ is the foreign price of the $i$ th intermediate input, $k_{i}$, used to produce the final $i$ th consumption good, $p_{k_{i}}$ is the domestic price of the $i$ th intermediate output, and $\varepsilon_{D k_{i}}$ is the price elasticity of the intermediate output. According to this specification, the production of the $i$ th consumption good requires only one kind of intermediate output, let us say $k_{i}$. We also consider the usual export and import functions for the final goods, respectively, as:

$$
\begin{aligned}
& x_{i}=\bar{x}_{i}\left(\frac{p_{i}}{e p_{F i}}\right)^{-\varepsilon_{F i}} Y_{F}^{\eta_{F i}} \\
& m_{i}=\bar{m}_{i}\left(\frac{p_{i}}{e p_{F i}}\right)^{\varepsilon_{D i}} Y_{D}^{\eta_{D i}}
\end{aligned}
$$

where $\bar{x}_{i}$ and $\bar{m}_{i}$ are a constant terms, $x_{i}$ is the export demand function for consumption good $i, m_{i}$ is the import demand function for consumption good $i, Y_{F}$ is the income of foreign country $F, p_{i}$ is the domestic price of the $i$ th good, $p_{F i}$ is the foreign price of the $i$ th good, $\eta_{F i} \geq 0$ and $\eta_{D i} \geq 0$ are the income elasticities of demand for the $i$ th good exports and imports, respectively, and $\varepsilon_{F i}$ and $\varepsilon_{D i}$ are the price elasticities of demand for the $i$ th good exports and imports, respectively. By differentiating expressions (1), (2) and (3), we obtain:

$$
\begin{aligned}
& \hat{m}_{k_{i}}=\varepsilon_{D k_{i}}\left(\hat{p}_{k_{i}}-\hat{e}-\hat{p}_{F k_{i}}\right)+\eta_{D k_{i}} \hat{Y}_{\mathrm{D}}+\gamma_{D k_{i}} \hat{x}_{i} \\
& \hat{x}_{i}=-\varepsilon_{F i}\left(\hat{p}_{i}-\hat{e}-\hat{p}_{F i}\right)+\eta_{F i} \hat{Y}_{\mathrm{F}} \\
& \hat{m}_{i}=\varepsilon_{D \hat{i}}\left(\hat{p}_{i}-\hat{e}-\hat{p}_{F i}\right)+\eta_{D i} \hat{Y}_{D}
\end{aligned}
$$

where $\hat{Y}_{D}$ is the domestic growth rate, $\hat{Y}_{F}$ is the foreign country growth rate, $\hat{p}_{F i}$ is the growth rate of price of the $i$ th good in a foreign country, $\hat{p}_{i}$ is the domestic growth rate of price of the $i$ th good, $\hat{p}_{F k_{i}}$ is the growth rate of price of the $k_{i}$ th intermediate good in foreign country, $\hat{p}_{k_{i}}$ is the domestic growth rate of price of the $k_{i}$ th intermediate good, and $\hat{e}$ is the growth rate of the nominal exchange rate.

Note that expression (4) is the multisectoral counterpart of the demand function for imports of intermediate goods introduced by Blecker and Ibarra (2013, p. 37). Following Araujo and Lima (2007), and unlike Nishi (2016), let us assume that there is no technical progress, which implies that: $\hat{p}_{k_{i}}=\hat{p}_{F k_{i}}=\hat{p}_{i}=\hat{p}_{F i}=0, \forall i=1, \ldots, n-1$, which also means zero inflation rate in both countries for all goods. ${ }^{4}$ Besides, let us consider that

\footnotetext{
${ }^{4}$ Nowithstanding commodity prices may affect the trade performance of sectors that produce and export them; the producers do not control them. This view is in accordance with the literature on the terms of trade which considers that the price of commodities is determined within competitive markets in which the merchant houses play a decisive role, with few rooms left for the producers to establish them. Then, we consider that price competition does not play a decisive role insofar as the developing countries have few powers to control them. Blecker and Ibarra (2013) agreed with this view when they reasonably assume that the growth rate of the price of the primary goods grows at an exogenously given rate, presuming that conditions in global commodity markets determine them. Since we are dealing with a generalization of the Blecker and Ibarra (2013) approach, we preferred to assume that prices are neither increasing nor decreasing, which is also consistent with the non-existence of technological change.
} 
$\hat{e}=0$, meaning that neither continuous devaluations nor continuous overvaluations are allowed. Substituting (5) in (4) allows us to obtain:

$$
\begin{aligned}
& \hat{m}_{k_{i}}=\eta_{D k_{i}} \hat{Y}_{\mathrm{D}}+\gamma_{D k_{i}} \eta_{F i} \hat{Y}_{\mathrm{F}} \\
& \hat{x}_{i}=\eta_{F i} \hat{Y}_{F} \\
& \hat{m}_{i}=\eta_{D i} \hat{Y}_{D}
\end{aligned}
$$

From Araujo and Teixeira (2004) and Nishi (2016), the BoP equilibrium in the presence of intermediate inputs may be written as:

$$
\sum_{i=1}^{n-1} p_{i} x_{i}=\sum_{i=1}^{n-1}\left(e p_{F i} m_{i}+e p_{F k_{i}} m_{k_{i}}\right)
$$

Expression (10) considers that in equilibrium the imports of final and intermediate must be wholly financed by exports since we are not considering the possibility of capital inflows, external debt, etc. Then the main change about Araujo and Lima (2007) is that now the domestic country imports two different goods, namely final goods and intermediate goods. But, unlike Blecker and Ibarra (2013), we do not assume that the prices of such goods are the same. By differentiating expression (10) concerning time, it yields after some algebraic manipulation the following expression:

$$
\sum_{i=1}^{n-1}\left[\frac{p_{i} x_{i}\left(\hat{p}_{i}+\hat{x}_{i}\right)}{\sum_{i=1}^{n-1} p_{i} x_{i}}-\frac{e p_{F i} m_{i}\left(\hat{e}+\hat{p}_{F i}+\hat{m}_{i}\right)+e p_{F k_{i}} m_{k_{i}}\left(\hat{e}+\hat{p}_{F k_{i}}+\hat{m}_{k_{i}}\right)}{\sum_{i=1}^{n-1} e\left(p_{F i} m_{i}+p_{F k_{i}} m_{k_{i}}\right)}\right]=0
$$

Following Nishi (2016), we define $v_{i}=\frac{p_{i} x_{i}}{\sum_{i=1}^{n-1} p_{i} x_{i}}$ as the market share of the $i$ th industry in a domestic country's total exports, $\mu_{i}=\frac{\sum_{i=1}^{n-1} e p_{F i} m_{i}}{\sum_{i=1}^{n} e\left(p_{F i} m_{i}+p_{F k_{i}} m_{k_{i}}\right)}$ as denoting the market share of the $i$ th industry in the domestic country's total imports and $\omega_{k_{i}}=\frac{e p_{F k_{i}} m_{k_{i}}}{\sum_{i=1}^{n-1} e\left(p_{F i} m_{i}+p_{F k_{i}} m_{k_{i}}\right)}$ as denoting the market share of the intermediate $k_{i}$ th industry in the domestic country's total imports, with $v_{i}, \mu_{i}$ and $\omega_{k_{i}} \in[0,1]$. It should also be noted that $\sum_{i=1}^{n-1} v_{i}=\sum_{i=1}^{n-1}\left(\mu_{i}+\omega_{k_{i}}\right)=1$. Considering that $\hat{p}_{k_{i}}-\hat{e}-\hat{p}_{F k_{i}}=\hat{p}_{i}-\hat{e}-\hat{p}_{F i}=0$ and replacing these expressions in (11) one obtains:

$$
\sum_{\hat{i}=1}^{n-1} v_{i} \hat{x}_{i}=\sum_{i=1}^{n-1} \mu_{i} \hat{m}_{i}+\sum_{i=1}^{n-1} \omega_{k_{i}} \hat{m}_{k_{i}}
$$

By substituting (7), (8) and (9) in (12), it yields after some algebraic manipulation, the growth rate consistent with the BoP equilibrium:

$$
\hat{Y}_{D}=\frac{\sum_{i=1}^{n-1}\left(v_{i}-\omega_{k_{i}} \gamma_{D k_{i}}\right) \eta_{F i}}{\sum_{i=1}^{n-1}\left(\mu_{i} \eta_{D i}+\omega_{k_{i}} \eta_{D k_{i}}\right)} \hat{Y}_{F}
$$

Expression (13) is a generalization of the MSTL since if $\omega_{k_{i}}=0, \forall i=1, \ldots, n-1$, we obtain the result derived by Araujo and Lima (2007) without intermediate inputs. Note that even in the case where the sectoral income export elasticities are constant, a 
country can achieve higher growth rates by increasing the export share of those sectors with higher income elasticities for exports. ${ }^{5}$ But now both the numerator and denominator incorporate the presence of foreign content of export. In the denominator, it is just a matter of decomposition of the imports between final and intermediate goods that were not taken into consideration in the original MSTL. However, the most important difference is in the numerator, where the income elasticity of exports is decreasing in those sectors where intermediate inputs are imported. The additional message that accrues from expression (13) is that the growth rate consistent with intertemporal equilibrium in the $\mathrm{BoP}$ is lower in the presence of intermediate goods being imported to master final goods to export.

Although this result is akin to the one obtained by Blecker and Ibarra (2013), it is worthy to highlight a substantial difference. Those authors have considered a particular structure for the economy, with the export sectors, for instance, being disaggregated in two sectors, namely manufactured and other goods, the latter comprising primary commodities, chiefly oil and agricultural products. The authors then reasonably assume that both the growth rate of exports of the primary goods and their price grow at an exogenously given rate, presuming that conditions in global commodity markets determine their quantities and prices. Here we do not make these assumptions insofar as our first aim was just to obtain a generalization of the MSTL. Although we do not assume a structure ex-ante for the economy, the model can accommodate such sectoral arrangements with minor changes in the outcome.

\section{Empirical and numerical analysis}

\subsection{Econometric analysis}

As previously stated, one of the aims of this paper consists in comparing the predictive power of the original MSTL and the version presented here with foreign content of exports. To reckon the BPCG rate, we have estimated two different versions of the MSTL, namely the one by Araujo and Lima (2007) and expression (13) derived here in the presence of intermediate goods. For the former, according to the methodology adopted by Gouvea and Lima (2010), we consider that all imported goods are computed as final goods, not admitting the existence of foreign content of exports. For the latter, we have split imports into two categories, namely final and intermediate goods. In this regard, we intend to evaluate which of these versions is best suited to explain the economic growth in Mexico from 1962 to 2014.

To proceed to this empirical exercise, due to the high complexity of the economic structure of Mexico, we have focused only on the six major sectors in the Mexican trade in 2014 according to the United Nations Commodity Trade Statistics Database (COMTRADE). The nomenclature of these sectors and their abbreviations are: (1) food

\footnotetext{
${ }^{5}$ As we are assuming there is no technical progress, which implies that: $\hat{p}_{k_{i}}=\hat{p}_{F k_{i}}=\hat{p}_{i}=\hat{p}_{F i}=0, \forall i=1, \ldots, n-1$, then what matters for the dynamics of the shares is the dynamics of quantum. By its turn, the dynamics of quantum depends on the comparative cost advantage structure of a country. We recognize that a number of factors can affect this structure, but it goes beyond the aim of this paper try to understand the dynamics of the share of exports and imports. Authors such as Araujo (2012) and Missio et al. (2017) for instance have studied how the management of nominal and real exchange rate, respectively, can improve the share of sectors with higher income elasticity of demand in the exports, thus fostering growth in a BPCG setup. But beforehand, it is not possible to fully endogenize the shares of each of the sectors insofar as they will depend on a number of variables.
} 
and live animals (prim), (2) crude materials, inedible, except fuels (crudem), (3) mineral fuels, lubricants and related materials (lowm), (4) manufactured goods classified chiefly by material (midm), (5) machinery and transport equipment (highm), and (6) miscellaneous manufactured articles (others). All these sectors are organized according to the catalog of the Standard International Trade Classification Revision 1 (SITC-Rev. 1). From this information, we have reckoned the sectoral trade as well as the relative share of exports and imports in the trade sector. The other variables used, namely the economic growth rate of Mexico (gdpmex), the growth rate of the world economy (gdpwld) and the growth rate of the bilateral real exchange rate (exch) were drawn from the World Development Indicators (WDI). Although the relevant equations of the theoretical model were derived regarding growth rates, we have decided to follow Gouvea and Lima (2010) and Blecker and Ibarra (2013) who estimated the model by using data in logarithm by using the Johansen (2001) methodology.

Figure 1 shows the evolution of the relative share of sectors in the export of Mexico over the past decades. As can be seen, on the one hand, the more technology-intensive products, namely, the machinery and transport products hold a stake of approximately $65 \%$ of the exports against $2 \%$ which they had in 1962 . On the other hand, primary products, which once held a $37.5 \%$ share in the exports, now have only $5.5 \%$. That shows that there has been, to some extent, a structural shift in favor of sectors with a higher income elasticity of demand as pointed out by Gouvea and Lima (2010), implying a better growth performance. This range of view is supported by Blecker and Ibarra (2013, p. 34): 'Mexico's exports shifted toward more technologically advanced products with higher income elasticities in a way that more resembles the East Asian countries rather than other Latin American nations in their sample.' However, such changes in the composition of exports were not sustained across years and did not reflect their heavy dependency on foreign content of exports.

Figure 2 illustrates the evolution of the relative share of each sector in imports from 1962 to 2015. While, the imports of hi-tech products (highm) decreased by four percentage points or so, the share of intermediate goods (midm) Mexico has increased in the imports by approximately four percentage points between 1964 and 2015. In this sense, in the light of the structural change theory (see Araujo and Lima 2007; Blecker 2009; Thirlwall 2013), it can be said that structural changes implemented on the export front was somewhat offset by the deterioration of the composition of the imports, slowing the pace of economic growth in Mexico after deepening of trade liberalization (MorenoBrid 1999, 2002; Pacheco-López and Thirlwall 2004).

The reflection of that on the dynamics of trade of the Mexican economy can be seen in Fig. 3, which shows the trend observed in the growth rate of GDP of Mexico and the world growth rate since 1962. Note that the Mexico average per capita economic growth in the first 25 years $(2.86 \%)$ was higher than the average of the last 30 years $(0.88 \%)$. Moreover, the annual Mexico average per capita economic growth (1.78\%) was close to the growth rate of the world per capita income (1.79\%). Other factors such as the fierce competition of the Chinese producers in the US market after China entry in the WTO in 2001 and repeated economic crisis may help to explain such performance, leading Blecker and Ibarra (2013) to conclude that the external constraint was not binding through the whole period. That shows evidence that had Mexico succeeded in 

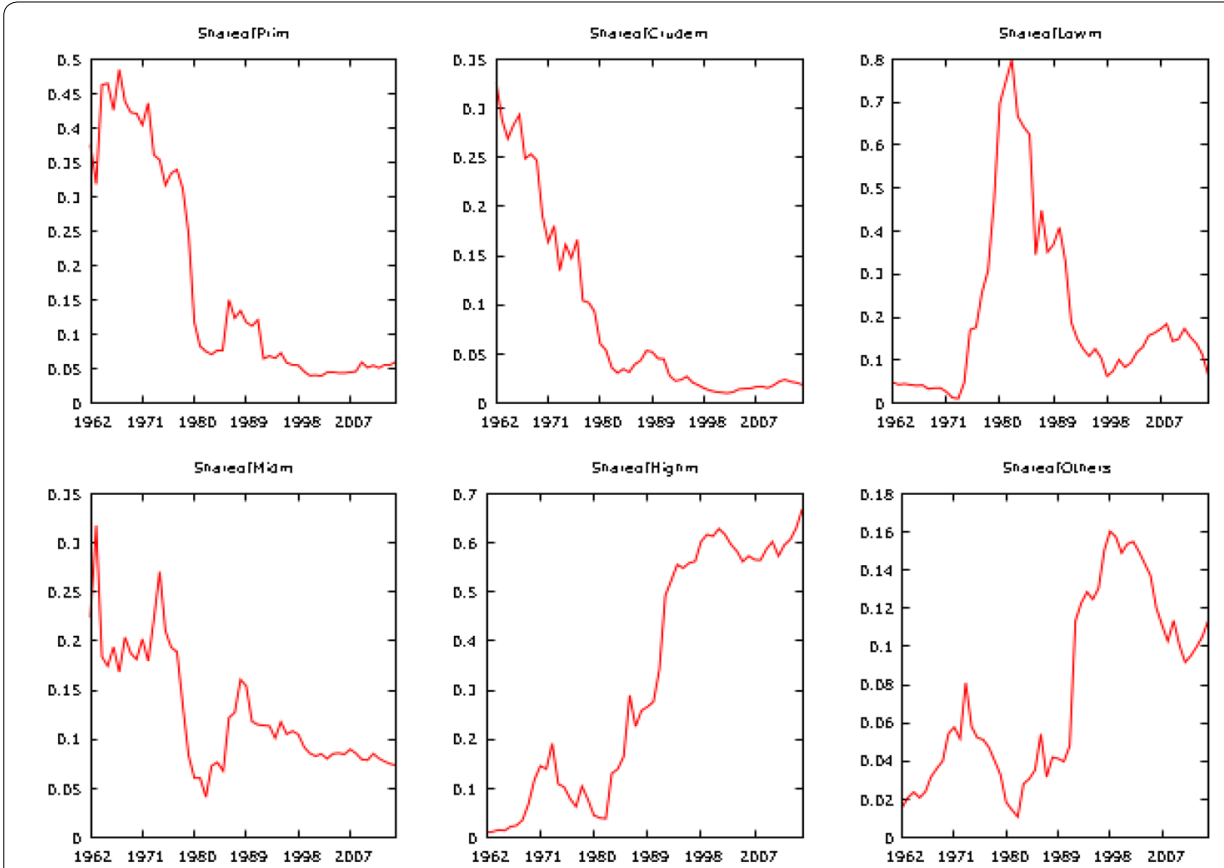

Fig. 1 Evolution of relative participation of exports of Mexico between 1962 and 2015. Source: Elaborate by the authors with data from COMTRADE

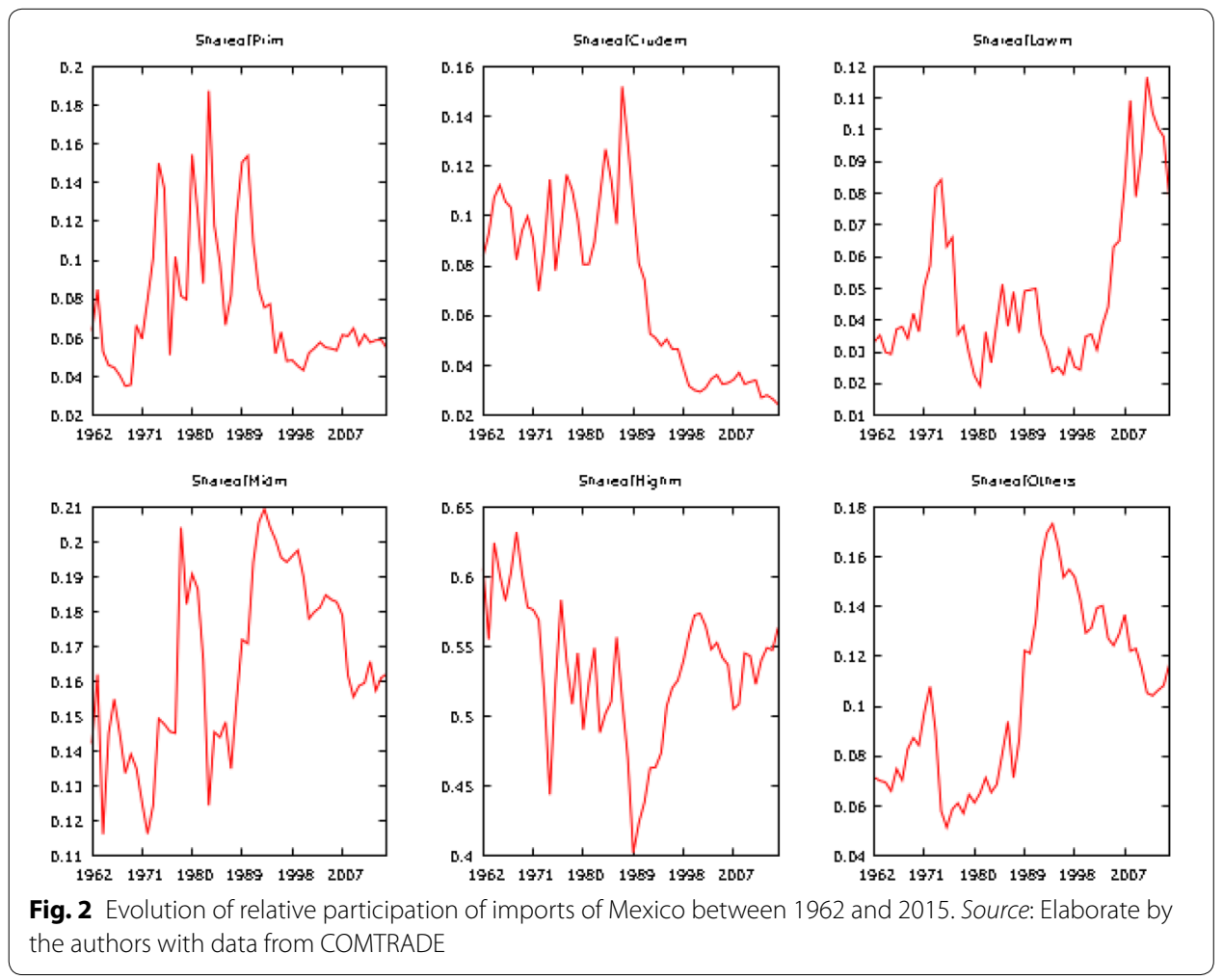




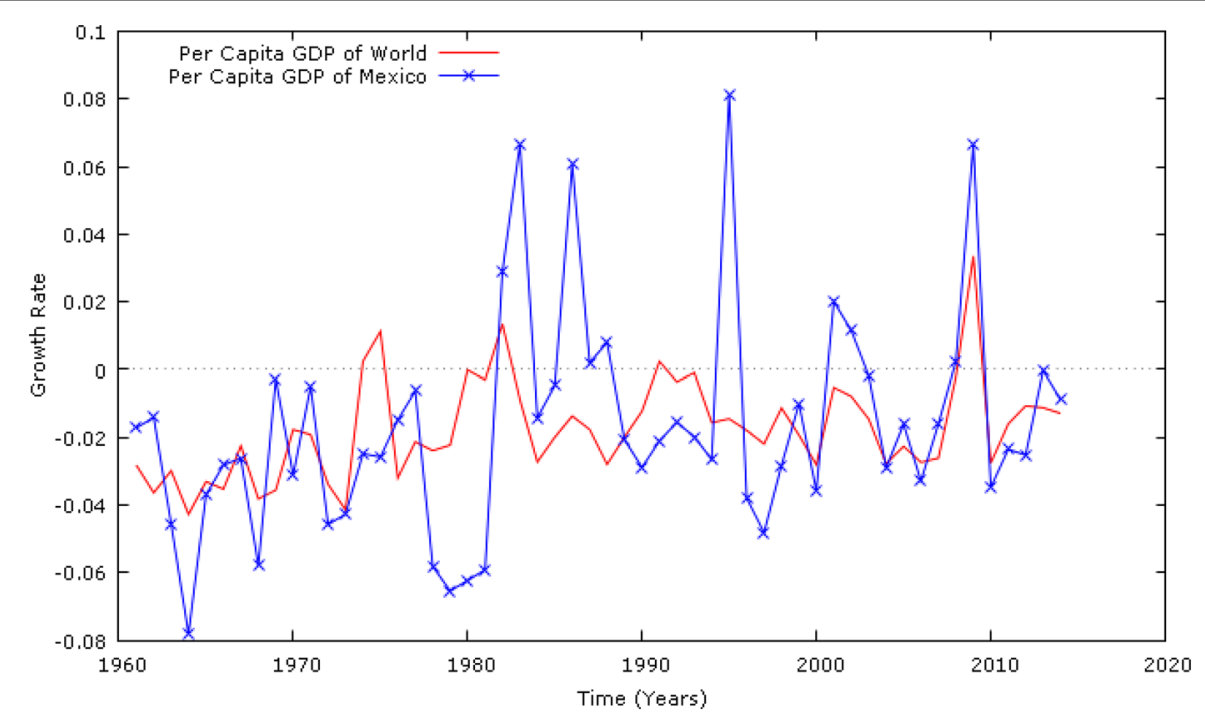

Fig. 3 Mexico and world GDP economic growth between 1960 and 2014. Source:WDI

performing a complete structural change; then it would keep growth rates consistent with those in the pre-liberalization period (see Blecker and Ibarra 2013).

Table 1 shows the result of the unit root tests. Among the available tests, we used are the Augmented Dickey-Fuller (ADF), Phillips-Perron (PP) and Kwiatkowski-PhillipsSchmidt-Shin (KPSS), whose results are shown below. Although all series but the real exchange rate one was found to be integrated of the first order, all of the series in the first difference is stationary at $1 \%$ regardless of the test adopted. Hence, the Johansen (2001) test was used to determine whether the I(1) series are cointegrated. Then, whenever it is not possible to reject the null hypothesis of the existence of at least one cointegration vector, we estimate the equations by the Johansen method. The advantage of such an approach is that there is no loss of information since all variables are in levels.

Due to the lack of data available for the sectoral prices in the period considered, we used the rate of the effective bilateral real exchange rate (US-Mexico) as a proxy for the sectoral real exchange growth rate (see Gouvea and Lima 2010), which corresponds to the growth rate of the effective bilateral real exchange rate. Besides, we have considered that sector 'prim,' 'midm' and 'crudem' as intermediate import goods that are used to produce the final goods of the 'highm' sector. This choice rested on the fact that the 'highm' sector is essentially a final good sector. Also, according to World Input-Output Data (WIOD), goods from 'prim,' 'mid' and 'crudem' sectors are commonly used as an intermediate for the Mexican economy. Although there is no perfect matching between the COMTRADE database and the input-output matrix of Mexico available in the WIOD, ${ }^{6}$ we have found that sectors such as the 'prim,' 'midm' and 'crudem' sectors have high participation as intermediate goods in other sectors, like 'highm,' as can be found

\footnotetext{
${ }^{6}$ The data provided by COMTRADE do not provide sufficient information regarding the linkages between the inputoutput matrix of the countries. The alternative we found was to use the data provided by WIOD to identify the sectors (and the correspondence between the sectors is not perfect) and the relation that these have with the intermediate inputs. Ideally, we should work with WIOD data, but its time range is too short. That way, the best we can do is merge information between the tables of WIOD (2000-2011) and COMTRADE (1962-2014).
} 
Table 1 Results of unit roots tests. Source: Elaborated by the author

\begin{tabular}{|c|c|c|c|c|c|c|c|c|}
\hline \multirow[t]{2}{*}{ Series/tests } & \multicolumn{2}{|l|}{$\mathrm{ADF}$} & \multicolumn{2}{|l|}{ PP } & \multicolumn{2}{|l|}{ KPSS } & \multicolumn{2}{|l|}{ Concl. } \\
\hline & Level & Diff. & Level & Diff. & Level & Diff. & Level & Diff. \\
\hline LN(realexch) & $-3.13^{* *}$ & $-7.28^{* * *}$ & $-3.12^{* *}$ & $-9.85^{* * *}$ & 0.12 & 0.18 & $\mathrm{I}(0)$ & $\mid(0)$ \\
\hline LN(xprim) & -0.49 & $-7.86^{* * *}$ & -0.41 & $-9.24^{* * *}$ & $0.87 \Delta \Delta \Delta$ & 0.11 & $\mathrm{I}(1)$ & $I(0)$ \\
\hline LN(xcrudem) & -0.13 & $-7.40^{* * *}$ & $-3.29^{*}$ & $-7.74^{* * *}$ & $0.85 \Delta \Delta \Delta$ & 0.11 & $\mid(1)$ & $I(0)$ \\
\hline LN(xlowm) & -1.49 & $-4.42^{* * *}$ & -1.45 & $-4.45^{* * *}$ & $0.71 \Delta \Delta$ & 0.17 & $\mid(1)$ & $I(0)$ \\
\hline LN(xmidm) & -1.00 & $-7.37^{* * *}$ & -0.76 & $-9.22^{* * *}$ & $0.86 \Delta \Delta \Delta$ & 0.12 & $\mathrm{I}(1)$ & $\mathrm{I}(0)$ \\
\hline LN(xhighm) & -2.10 & $-7.09^{* * *}$ & -2.15 & $-7.09^{* * *}$ & $0.86 \Delta \Delta \Delta$ & $0.37 \Delta$ & $\mid(1)$ & $I(0)$ \\
\hline LN(xotherm) & -1.37 & $-7.30^{* * *}$ & -1.38 & $-7.30^{* * *}$ & $0.85 \Delta \Delta \Delta$ & 0.18 & $\mid(1)$ & $\mathrm{I}(0)$ \\
\hline LN(mprim) & -1.24 & $-7.54^{* * *}$ & -1.31 & $-8.19^{* * *}$ & $0.17 \Delta \Delta$ & 0.09 & $\mid(1)$ & $I(0)$ \\
\hline LN(mcrudem) & -2.01 & $-8.08^{* * *}$ & $-3.31^{* *}$ & $-7.83^{* * *}$ & $0.22 \Delta \Delta \Delta$ & $0.38 \Delta$ & $\mathrm{I}(1)$ & $\mathrm{I}(0)$ \\
\hline LN(mlowm) & -0.71 & $-7.76^{* * *}$ & -0.63 & $-8.42^{* * *}$ & $0.86 \Delta \Delta \Delta$ & 0.07 & $\mid(1)$ & $I(0)$ \\
\hline LN(mmidm) & -1.02 & $-6.06^{* * *}$ & -1.10 & $-6.39^{* * *}$ & $0.85 \Delta \Delta \Delta$ & 0.15 & $\mid(1)$ & $\mathrm{I}(0)$ \\
\hline LN(mhighm) & -0.77 & $-6.46^{* * *}$ & -0.80 & $-6.97^{* * *}$ & $0.86 \Delta \Delta \Delta$ & 0.12 & $\mid(1)$ & $I(0)$ \\
\hline LN(motherm) & -1.01 & $-5.92^{* * *}$ & -1.04 & $-5.83^{* * *}$ & $0.86 \Delta \Delta \Delta$ & 0.14 & $\mathrm{I}(1)$ & $I(0)$ \\
\hline LN(gdpmex) & -1.64 & $-6.61^{* * *}$ & -2.22 & $-5.91^{* * *}$ & $0.96 \Delta \Delta \Delta$ & 0.25 & $\mid(1)$ & $I(0)$ \\
\hline LN(gdpwld) & -2.05 & $-3.90^{* * *}$ & -2.35 & $-3.84^{* * *}$ & $0.96 \Delta \Delta \Delta$ & $0.44 \Delta$ & $\mid(1)$ & $I(0)$ \\
\hline
\end{tabular}

(1) *Stationary at $10 \%$; ** stationary at $5 \% ;{ }^{* * *}$ stationary at $1 \%$. (2) $\Delta$ Non-stationary at $10 \% ; \Delta \Delta$ non-stationary at $5 \%$; $\Delta \Delta \Delta$ non-stationary at $1 \%$

in table presented in "Appendix". Besides, this observation is consistent with our econometric results, which we will be shown in Table $3 .{ }^{7}$

Table 2 presents the results of the econometrically estimated parameters by the Johansen method. Firstly, it may be noted that practically all parameters concerning the real exchange rate are statistically significant. It might be concluded that changes regarding trade play a role (Ibarra and Blecker 2016), that is, effects from real exchange rate affected the Mexican trade performance in recent decades substantially. That is especially true for the 'prim,' 'lowm' and 'others.' Furthermore, as expected, all sectoral parameters related to the growth rate of both domestic and foreign income were statistically significant at $1 \%$. On the one hand, the results highlight 'others' and 'highm' are the most important one for growth in Mexico during the period analyzed regarding the ratio of the income elasticities. On the other hand, the intermediate import sectors have shown to be playing a negative effect on the elasticity ratio and, hence on the growth performance.

Figure 4 shows the evolution of the ratio of the income elasticities weighted by the sector share in the Mexico trade. Note that the ratio of the elasticities in the model with intermediate inputs is lower than the ratio of the elasticities in the traditional MSTL. However, until 1982, the difference between the ratios of elasticities is almost negligible, while from 1982 on, that difference increased slightly. This fact indicates that the imports of intermediate inputs did not matter significantly to explain the Mexican growth performance in the pre-liberalization period-first 20 years of the series. In the mid-eighties, however, foreign content of exports acquired a more prominent position

\footnotetext{
7 The elasticities extracted through Johansen method (2001) allow us not to use the structural break test because the cointegration ensures a long-term stable relationship between the variables and the short-term deviation are corrected by the Vector Error Correction (VEC).
} 
Table 2 Estimated parameters for the Mexican economy (1962-2014). Source: Elaborated by the authors

\begin{tabular}{llllllll}
\hline Sectors/Param. & $\eta_{F i}$ & $\varepsilon_{F i}$ & $\varepsilon_{D i}$ & $\eta_{D i}$ & $\varepsilon_{D k_{i}}$ & $\eta_{D k_{i}}$ & $\gamma_{D k_{i}}$ \\
\hline prim & $0.82^{* * *}$ & $1.18^{* *}$ & $3.46^{* * *}$ & $1.15^{* * *}$ & $1.66^{* *}$ & $0.37^{* *}$ & $0.72^{* * *}$ \\
& $(0.03)$ & $(0.38)$ & $(0.94)$ & $(0.09)$ & $(0.72)$ & $(0.18)$ & $(0.17)$ \\
crudem & $0.75^{* * *}$ & 0.74 & $1.36^{* * *}$ & $0.94^{* * *}$ & $0.55^{*}$ & $0.59^{* * *}$ & $0.32^{* * *}$ \\
& $(0.04)$ & $(0.51)$ & $(0.39)$ & $(0.03)$ & $(0.28)$ & $(0.07)$ & $(0.06)$ \\
lowm & $0.83^{* * *}$ & 1.14 & $5.43^{* * *}$ & $1.32^{* * *}$ & - & - & - \\
& $(0.24)$ & $(2.94)$ & $(1.30)$ & $(0.12)$ & - & - & - \\
midm & $0.93^{* * *}$ & $2.49^{* *}$ & $4.67^{* * *}$ & $1.29^{* * *}$ & $2.08^{* *}$ & $0.59^{* * *}$ & $0.49^{* * *}$ \\
& $(0.09)$ & $(1.15)$ & $(1.05)$ & $(0.10)$ & $(0.90)$ & $(0.13)$ & $(0.09)$ \\
highm & $1.25^{* * *}$ & $6.06^{*}$ & $4.18^{* * *}$ & $1.29^{* * *}$ & - & - & - \\
& $(0.29)$ & $(3.56)$ & $(0.89)$ & $(0.08)$ & - & - & - \\
Others & $1.21^{* * *}$ & $6.04^{* *}$ & $5.00^{* * *}$ & $1.31^{* * *}$ & - & - & - \\
& $(0.21)$ & $(2.59)$ & $(1.37)$ & $(0.13)$ & - & - \\
\hline
\end{tabular}

(1) * Statistically significant at 10\%; ** statistically significant at $5 \%$; ${ }^{* *}$ statistically significant at $1 \%$. (2) Standard error in parentheses

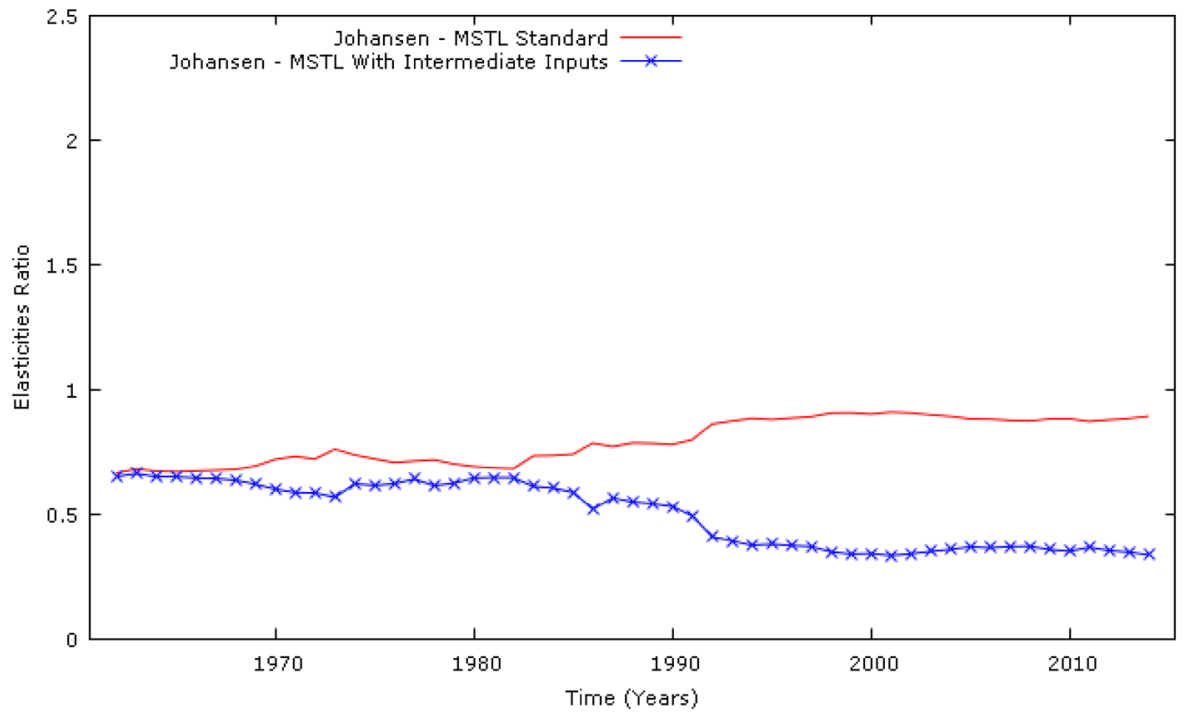

Fig. 4 Evolution of the Mexican ratio of income elasticities between 1962 and 2014. Source: Elaborated by the authors

in explaining the differences between the estimates. Therefore, we conclude that the imports of intermediate goods due to foreign content of exports are of some importance to understanding the reduction both in the ratio of the income elasticities and the growth rate of the Mexican economy, a result also found by Ibarra (2011). Therefore, Fig. 4 highlights that by using estimates from the version of the MSTL with intermediate goods, namely expression (13), we can explain the decay in the ratio of export to import income elasticities after trade liberalization reported by some authors such as MorenoBrid $(1999,2002)$ and Pacheco-López and Thirlwall (2004).

To further evaluate the effects of a strategy heavily dependent on intermediate inputs, we have run numerical simulations by using the elasticities estimated with the Johansen 


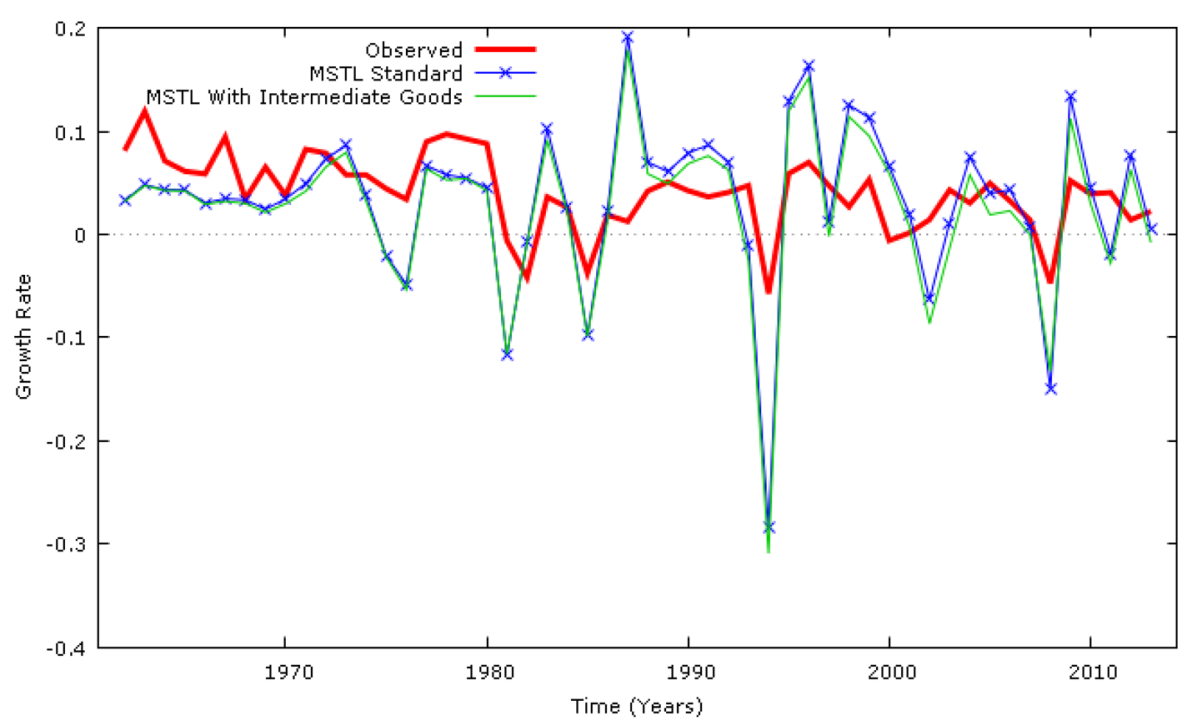

Fig. 5 Comparison of the Mexican economic growth rate observed and foreseen. Source: Elaborated by the authors

method in Table 2. By performing a forecasting exercise, we have found that the average absolute error of the forecast made by the traditional model was $3.90 \%$ while the model with intermediate goods, $3.00 \%$. Therefore, there is a difference of approximately $30 \%$ between the predictions of both models. Moreover, the results show that the intermediate goods version of the MSTL generates better forecast results for Mexico's growth rate in the observed period.

Figure 5 shows that, for some periods, the observed growth rate is higher than the predicted one, but, for others, the predicted growth rates are lower than the observed one. In the first 10 years, the observed growth rates were, consistently, higher than the predicted growth rate by both methods. The results also show that by considering the original MSTL the Mexican growth experience after NAFTA is not BoP constrained, a result that is tantamount to the one obtained by Ibarra and Blecker (2016). ${ }^{8}$ According to them, other factors than the BoP constraint should be considered to explain Mexican growth performance since 1962.

To decide which model best fit the data, a regression of the rate observed with the rates set by the two cases was performed-see Table 3. As can be seen, the results show that MSTL with intermediate goods performs better than the original MSTL insofar as the adjusted R-squared for the former is slightly higher than that of the latter. This result is confirmed by additional statistical tests such as BIC, AIC, RMSE, and loglikelihood. Our conclusions accrue from the fact that the lower the values of the BIC, AIC and RMSE statistics the best the fit of the model under consideration, which allows us to conclude that

\footnotetext{
${ }^{8}$ Basically, the results obtained by Blecker and Ibarra (2013) show that Mexico grew above that predicted by the model with restriction in BP during the pre-liberalization years of 1960-1986. In addition, they also showed that there is no empirical evidence that a higher restriction in the Mexican BP explained the deceleration of growth in the post-liberalization period. In our paper, Mexico experienced economic growth close to that of BP's equilibrium during the entire period.
} 
Table 3 Comparison of the adjusted level of both forecasts. Source: Elaborated by the authors

\begin{tabular}{lcc}
\hline$\hat{Y}_{D}$ & MSTL standard & $\begin{array}{l}\text { MSTL } \\
\text { with intermediate } \\
\text { goods }\end{array}$ \\
\hline Coefficient & $0.2645^{* * *}$ & $0.2739^{* * *}$ \\
Intercept & $(0.0564)$ & $(0.0563)$ \\
R-squared & $0.0316^{* * *}$ & $0.0336^{* * *}$ \\
Adjusted R-squared & $0.0047)$ & $(0.0044)$ \\
Loglikelihood & 0.3054 & 0.3209 \\
RMSE & 0.2915 & 0.3073 \\
HQC & 107.646 & 108.177 \\
AIC & 0.0322 & 0.0321 \\
SC & -3.9909 & -4.0135 \\
\hline
\end{tabular}

(1) *Statistically significant at $10 \%$; ** statistically significant at $5 \%$; *** statistically significant at $1 \%$. (2) Standard error in parentheses

the MSTL with intermediate inputs has a better fit than the standard one for the case of Mexico.

These results show that at least for the case of the Mexican economy since 1962, the version with intermediate goods is better to explain the Mexican economic growth than the original MSTL. A possible interpretation of such a result is that the imports of intermediate goods did play a decisive role for the Mexican growth in the post-liberalization periodafter 1982. Then, it is possible to infer that the MSTL with intermediate goods has a slight predictive advantage over the traditional one. Notwithstanding the predictive gain may be small, the theoretical conclusions are indeed relevant. By using the original MSTL in the presence of massive imports of intermediate goods with high-income elasticity can lead us to overestimate the growth performance in the long run, yielding an artificially higher income than what could be obtained by using the extended MSTL derived here. In fact, this will be better explained in the next subsection, by using a numerical simulation.

\subsection{Numerical simulation}

To further investigate the consequences when foreign content of exports is accounted for, the econometric results for the Mexican economy were used to feed a numerical routine. The sectoral income elasticities adopted in the simulations were drawn from Table 2, and the share of each sector in exports and imports was obtained from COMTRADE. These parameters were used to compare the performance of the Mexican economy under two scenarios, namely with and without disaggregating the imports regarding intermediate goods. Concerning the share of each sector in imports and exports, we have chosen to make them constant through time thus keeping the composition of exports and imports according to the values observed in 2014. Concerning the growth rate of the world income, we have used the expression (14) below to reckon it in each period:

$$
X_{t}=\mu+\sigma \varepsilon_{t}
$$

where $X_{t}$ is a stochastic process with a mean $\mu$ and standard error $\sigma$. The term $\varepsilon_{t}$ is a white noise. Then by considering the time span from 1962 to 2014, we have obtained 


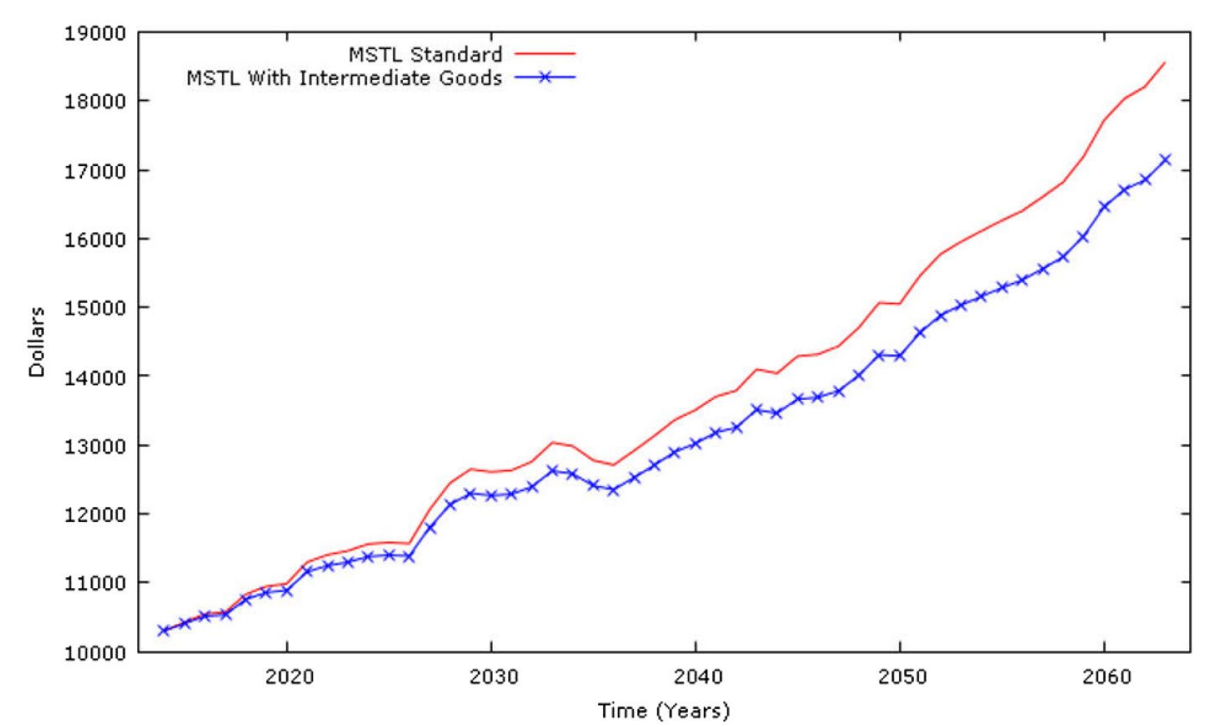

Fig. 6 Mexico PNB per capita evolution foreseen in both versions of MSTL (US\$). Source: Elaborated by the authors

$\mu=0.0133$ and $\sigma=0.0132$. With such information, and by using the parameters estimated econometrically it was possible to generate the growth rate of the Mexico economy under the two scenarios, namely with and without intermediate goods by using the following expression:

$$
Y_{D_{T}}=Y_{D_{1}}\left[\prod_{t=1}^{T}\left(1+g_{t}\right)-1\right]
$$

where $Y_{D_{T}}$ is the per capita income at the end of the period and $Y_{D_{1}}$ is the per capita income at time one; $g_{t}$ is the growth rate of income in the period $t$. Figure 6 shows the trajectory of per capita income in Mexico for the two simulated cases. In the scenario that ignores the foreign content of exports, from the current amount of US\$10,300.00, a per capita income of US\$18,565.46 is reached after 50 periods. In the alternative scenario, which considers the imports of intermediate goods, an income per capita of US\$ $17,135.86$ was reached after the same period.

Note that for each year the difference between the simulated economic growth rates is increasing-see Fig. 6-resulting in a not negligible difference in the values of per capita incomes at the end of the period-see Fig. 7. In the long run, the value of the difference in dollars corresponds to approximately to US\$1400.00, and in percentage, it amounts to $8.50 \%$.

Figure 7 shows that although the growth rates predicted by the two approaches are a small year by year, in the long run, there is a substantial difference in per capita income. In this sense, while a growth strategy based on foreign content of exports with high-income elasticity seems not to yield relevant differences in the BPCG rates, when we consider a broader time horizon, the small percentage differences in growth over time can cause large percentage differences in per capita income. In our simulation, for example, after 60 years, the country reaches a level of per capita income 


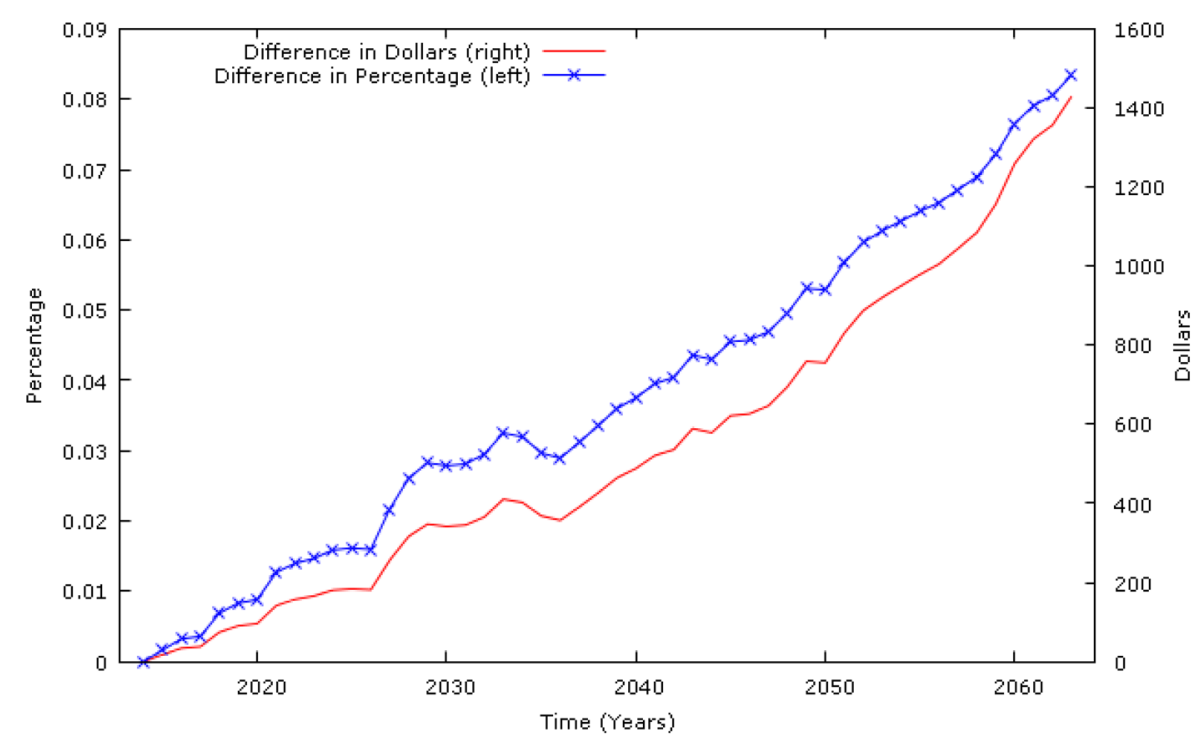

Fig. 7 Difference between accumulated Mexico foreseen PNB per capita in dollars and percentage. Source: Elaborated by the authors

approximately $8.5 \%$ higher with the original MSTL than what it would be with the extended MSTL. This may seem small, but for a per capita income of U\$ 9000.00, it means approximately $\mathrm{U} \$ 765.00$ less in the average income of the country.

This confirms what was stated in the final of the previous subsection, namely by using the original MSTL to estimate the BPCG rate in the presence of foreign content of exports can have some negative side effects mainly if the intermediate inputs present a high-income elasticity with respect to exports. Figures 6 and 7 are helpful to clarify this point. As it can be seen from them, the difference in the PNB per capita by using the original and the extended MSTL presents a meaningful difference in the long run, being higher in the first case. Therefore, the original MSTL tends to overestimate the per capita income in the long run. Finally, Fig. 8 confirms this view from the growth perspective. By using the extended MSTL, we conclude that the economy has a worse growth performance than that without intermediate inputs.

These results allow us to conclude that although Mexico has obtained some success regarding growth performance, the strategy of relying on massive foreign content of exports may be flawed insofar as it reduces the chance of catching up with advanced economies in the long run. In this vein, such results suggest that it is essential for Mexico to reduce its dependence on imports of intermediate goods with high-income elasticity concerning exports. So, we conclude that a growth strategy driven by the absence of imports of intermediate high-income elasticity goods is superior regarding the growth performance of an approach based on imports of such goods. On the one hand, a policy based on the imports of intermediate inputs would allow the country to export manufactured goods with a higher income elasticity of demand by enhancing the average income elasticity of exports. On the other hand, it also increases the average income elasticity of imports, mainly if the intermediate inputs present high elasticity concerning exports. 


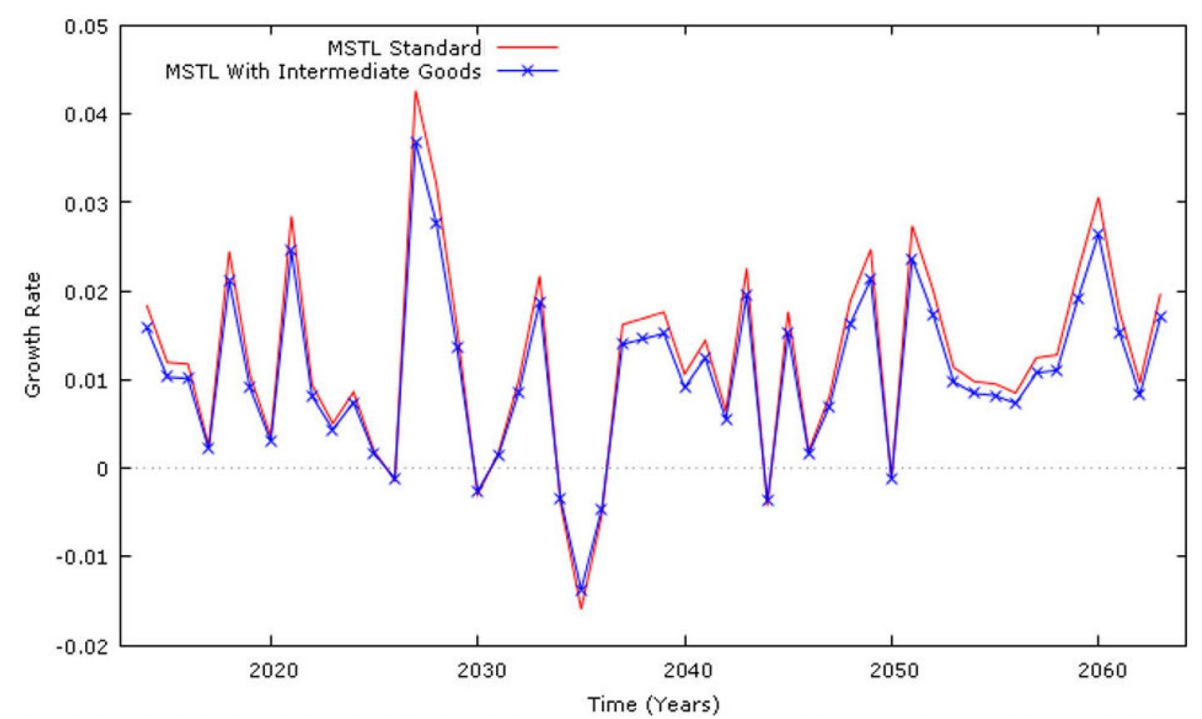

Fig. 8 Annual growth rates of Mexico in both scenarios. Source: Elaborated by the authors

\section{Concluding remarks}

In this paper, we study the effects of the imports of intermediate inputs on the growth performance. With such an analysis, we aimed at determining whether the presence of those goods in the imports of a country would imply a significant reduction in the BPCG rate. To that end, we have adopted a procedure similar to Blecker and Ibarra (2013) who included exports of manufactured goods in the demand function for imports of intermediate goods. By using this strategy within the SED model (Pasinetti 1993; Araujo and Teixeira 2004), it was possible to establish an extended version of the MSTL considering the foreign content of exports. The extended MSTL in the presence of intermediate inputs shows that a strategy based on foreign content of exports can indeed lead to a reduction in the growth rate compatible with the BoP equilibrium.

This result was econometrically tested for the Mexican economy by comparing the BPCG rate by using the traditional MSTL and the one derived here with intermediate inputs. From 1962 to 1982 -the pre-liberalization period-we have found that the estimates from the two versions are very close, but from 1982 on-the post-liberalization period-when a strategy based on foreign content of exports was adopted, the growth rate in the presence of intermediate goods is closer to the actual growth rate. By using the parameters from the two versions of the MSTL, we ran numerical simulations that confirmed that in the presence of foreign content of exports the BPCG rate is artificially high, confirming the analytical and econometric findings.

When comparing our findings with those of Blecker and Ibarra (2013), it is possible to conclude that the model advanced here considers the role of structural changes in a more overarching perspective than their model, which considers only two kinds of imports and exports. Unlike them, we do not need to search for other variables to explain the Mexican growth experience pre- and post-liberalization than those emphasized by the BPCG model. Notwithstanding providing a more inclusive role for the structure of the economy, the model advanced here is still not sufficient to consider all the details that an input-output analysis could reveal. So, we are not in a position to give a definite answer, 
for instance, on what would happen to the Mexican economy in the presence of a shortage of imported intermediate goods. What we can infer is that had Mexico not relied so much on the imports of intermediate inputs it could have experienced higher growth rates. Therefore, these findings reassert the central message of the MSTL, namely that, in the end, the growth rate of a country will depend on its structure, which is strongly reflected in the weighted export and import elasticities.

\section{Acknowledgements}

We wish to thank useful comments from two referees and also comments from the participants of the 42nd Annual Conference of Eastern Economic Association and the Conference of the FMM Research Network where preliminary versions of the paper were presented. The usual disclaimer applies.

\section{Authors' contributions}

All authors contributed equally in all sections. All authors read and approved the final manuscript.

\section{Funding}

Ricardo Araujo wishes to thank financial support from CNPq and Capes/Proex.

\section{Availability of data and materials}

We have focused only on the six major sectors in the Mexican trade in 2014 according to the United Nations Commodity Trade Statistics Database (COMTRADE). The other variables used, namely the economic growth rate of Mexico (gdpmex), the growth rate of the world economy (gdpwld) and the growth rate of the bilateral real exchange rate (exch), were drawn from the World Development Indicators (WDI).

\section{Competing interests}

None of the authors have any competing interests in the manuscript.

\section{Author details}

${ }^{1}$ Department of Economics, University of Brasilia, Campus Universitário Darcy Ribeiro, Brasília, DF 70910-900, Brazil.

2 Department of Economics, Catholic University of Brasilia, Campus I, Águas Claras, QS 07, Lote 01, EPCT, Brasília, DF CEP: 71966-700, Brazil. ${ }^{3}$ Department of Economics, Federal University of Uberlândia, Av. João Naves de Ávila, 2121, Uberlândia, MG CEP: 38400-902, Brazil.

\section{Appendix}

\begin{tabular}{|c|c|c|c|c|c|c|c|c|}
\hline$\#$ & $\begin{array}{l}\text { Sectors } \\
\text { in WIOD }\end{array}$ & $\begin{array}{l}\text { Input } \\
\text { to other } \\
\text { sectors }\end{array}$ & $\begin{array}{l}\text { Household } \\
\text { consumption }\end{array}$ & $\begin{array}{l}\text { Government } \\
\text { consumption }\end{array}$ & $\begin{array}{l}\text { Inputs } \\
\text { for investment }\end{array}$ & $\begin{array}{l}\text { Changes } \\
\text { in stocks }\end{array}$ & Exports & Total \\
\hline 1 & $\begin{array}{l}\text { Crop and } \\
\text { animal } \\
\text { production, } \\
\text { hunting } \\
\text { and related } \\
\text { service } \\
\text { activities }\end{array}$ & $62.10 \%$ & $18.97 \%$ & $0.00 \%$ & $1.45 \%$ & $4.87 \%$ & $12.61 \%$ & $100.00 \%$ \\
\hline 2 & $\begin{array}{l}\text { Forestry and } \\
\text { logging }\end{array}$ & $87.82 \%$ & $7.58 \%$ & $0.00 \%$ & $0.00 \%$ & $1.32 \%$ & $3.28 \%$ & $100.00 \%$ \\
\hline 3 & $\begin{array}{l}\text { Fishing and } \\
\text { aquaculture }\end{array}$ & $17.08 \%$ & $71.09 \%$ & $0.00 \%$ & $1.38 \%$ & $-0.27 \%$ & $10.72 \%$ & $100.00 \%$ \\
\hline 4 & $\begin{array}{l}\text { Mining and } \\
\text { quarrying }\end{array}$ & $46.57 \%$ & $0.00 \%$ & $0.00 \%$ & $11.92 \%$ & $-0.93 \%$ & $42.44 \%$ & $100.00 \%$ \\
\hline 5 & $\begin{array}{l}\text { Manufacture } \\
\text { of food } \\
\text { products, } \\
\text { beverages } \\
\text { and tobacco } \\
\text { products }\end{array}$ & $18.09 \%$ & $74.00 \%$ & $0.00 \%$ & $0.00 \%$ & $1.69 \%$ & $6.22 \%$ & $100.00 \%$ \\
\hline 6 & $\begin{array}{l}\text { Manufacture } \\
\text { of textiles, } \\
\text { wearing } \\
\text { apparel } \\
\text { and leather } \\
\text { products }\end{array}$ & $25.41 \%$ & $32.54 \%$ & $0.00 \%$ & $0.12 \%$ & $0.82 \%$ & $41.12 \%$ & $100.00 \%$ \\
\hline
\end{tabular}




\begin{tabular}{|c|c|c|c|c|c|c|c|c|}
\hline$\#$ & $\begin{array}{l}\text { Sectors } \\
\text { in WIOD }\end{array}$ & $\begin{array}{l}\text { Input } \\
\text { to other } \\
\text { sectors }\end{array}$ & $\begin{array}{l}\text { Household } \\
\text { consumption }\end{array}$ & $\begin{array}{l}\text { Government } \\
\text { consumption }\end{array}$ & $\begin{array}{l}\text { Inputs } \\
\text { for investment }\end{array}$ & $\begin{array}{l}\text { Changes } \\
\text { in stocks }\end{array}$ & Exports & Total \\
\hline 7 & $\begin{array}{l}\text { Manufacture } \\
\text { of wood and } \\
\text { of products } \\
\text { of wood and } \\
\text { cork, except } \\
\text { furniture; } \\
\text { manufac- } \\
\text { ture of arti- } \\
\text { cles of straw } \\
\text { and plaiting } \\
\text { materials }\end{array}$ & $82.49 \%$ & $7.86 \%$ & $0.00 \%$ & $0.12 \%$ & $1.93 \%$ & $7.60 \%$ & $100.00 \%$ \\
\hline 8 & $\begin{array}{l}\text { Manufacture } \\
\text { of paper } \\
\text { and paper } \\
\text { products }\end{array}$ & $67.13 \%$ & $17.81 \%$ & $0.00 \%$ & $0.00 \%$ & $3.32 \%$ & $11.74 \%$ & $100.00 \%$ \\
\hline 9 & $\begin{array}{l}\text { Printing and } \\
\text { reproduc- } \\
\text { tion of } \\
\text { recorded } \\
\text { media }\end{array}$ & $58.55 \%$ & $22.91 \%$ & $4.23 \%$ & $0.00 \%$ & $1.19 \%$ & $13.12 \%$ & $100.00 \%$ \\
\hline 10 & $\begin{array}{l}\text { Manufacture } \\
\text { of coke } \\
\text { and refined } \\
\text { petroleum } \\
\text { products }\end{array}$ & $68.16 \%$ & $21.05 \%$ & $0.00 \%$ & $0.00 \%$ & $2.78 \%$ & $8.01 \%$ & $100.00 \%$ \\
\hline 11 & $\begin{array}{l}\text { Manufacture } \\
\text { of chemicals } \\
\text { and chemi- } \\
\text { cal products }\end{array}$ & $59.66 \%$ & $22.46 \%$ & $0.00 \%$ & $0.01 \%$ & $3.44 \%$ & $14.44 \%$ & $100.00 \%$ \\
\hline 12 & $\begin{array}{l}\text { Manufacture } \\
\text { of basic } \\
\text { pharma- } \\
\text { ceutical } \\
\text { products } \\
\text { and phar- } \\
\text { maceutical } \\
\text { preparations }\end{array}$ & $27.69 \%$ & $58.38 \%$ & $0.00 \%$ & $0.00 \%$ & $3.81 \%$ & $10.12 \%$ & $100.00 \%$ \\
\hline 13 & $\begin{array}{l}\text { Manufacture } \\
\text { of rubber } \\
\text { and plastic } \\
\text { products }\end{array}$ & $62.73 \%$ & $9.11 \%$ & $0.00 \%$ & $0.00 \%$ & $1.71 \%$ & $26.45 \%$ & $100.00 \%$ \\
\hline 14 & $\begin{array}{l}\text { Manufacture } \\
\text { of other } \\
\text { non-metallic } \\
\text { mineral } \\
\text { products }\end{array}$ & $64.78 \%$ & $19.47 \%$ & $0.00 \%$ & $0.07 \%$ & $1.38 \%$ & $14.31 \%$ & $100.00 \%$ \\
\hline 15 & $\begin{array}{l}\text { Manufacture } \\
\text { of basic } \\
\text { metals }\end{array}$ & $66.01 \%$ & $0.19 \%$ & $0.00 \%$ & $1.97 \%$ & $2.05 \%$ & $29.77 \%$ & $100.00 \%$ \\
\hline 16 & $\begin{array}{l}\text { Manufacture } \\
\text { of fabricated } \\
\text { metal prod- } \\
\text { ucts, except } \\
\text { machinery } \\
\text { and equip- } \\
\text { ment }\end{array}$ & $46.38 \%$ & $8.51 \%$ & $0.00 \%$ & $3.29 \%$ & $0.79 \%$ & $41.03 \%$ & $100.00 \%$ \\
\hline 17 & $\begin{array}{l}\text { Manufacture } \\
\text { of computer, } \\
\text { electronic } \\
\text { and optical } \\
\text { products }\end{array}$ & $9.38 \%$ & $1.08 \%$ & $0.00 \%$ & $1.61 \%$ & $-0.96 \%$ & $88.88 \%$ & $100.00 \%$ \\
\hline
\end{tabular}




\begin{tabular}{|c|c|c|c|c|c|c|c|c|}
\hline \# & $\begin{array}{l}\text { Sectors } \\
\text { in WIOD }\end{array}$ & $\begin{array}{l}\text { Input } \\
\text { to other } \\
\text { sectors }\end{array}$ & $\begin{array}{l}\text { Household } \\
\text { consumption }\end{array}$ & $\begin{array}{l}\text { Government } \\
\text { consumption }\end{array}$ & $\begin{array}{l}\text { Inputs } \\
\text { for investment }\end{array}$ & $\begin{array}{l}\text { Changes } \\
\text { in stocks }\end{array}$ & Exports & Total \\
\hline 18 & $\begin{array}{c}\text { Manufacture } \\
\text { of electrical } \\
\text { equipment }\end{array}$ & $7.59 \%$ & $1.50 \%$ & $0.00 \%$ & $0.86 \%$ & $0.12 \%$ & $89.93 \%$ & $100.00 \%$ \\
\hline 19 & $\begin{array}{l}\text { Manufacture } \\
\text { of machin- } \\
\text { ery and } \\
\text { equipment } \\
\text { n.e.c. }\end{array}$ & $12.30 \%$ & $1.46 \%$ & $0.00 \%$ & $5.93 \%$ & $0.10 \%$ & $80.21 \%$ & $100.00 \%$ \\
\hline 20 & $\begin{array}{l}\text { Manufacture } \\
\text { of motor } \\
\text { vehicles, } \\
\text { trailers and } \\
\text { semi-trailers }\end{array}$ & $13.48 \%$ & $24.00 \%$ & $0.00 \%$ & $5.76 \%$ & $-0.86 \%$ & $57.61 \%$ & $100.00 \%$ \\
\hline 21 & $\begin{array}{l}\text { Manufacture } \\
\text { of other } \\
\text { transport } \\
\text { equipment }\end{array}$ & $8.22 \%$ & $1.84 \%$ & $0.00 \%$ & $16.47 \%$ & $-3.96 \%$ & $77.43 \%$ & $100.00 \%$ \\
\hline 22 & $\begin{array}{l}\text { Manufacture } \\
\text { of furniture; } \\
\text { other manu- } \\
\text { facturing }\end{array}$ & $31.67 \%$ & $18.51 \%$ & $0.00 \%$ & $2.59 \%$ & $0.46 \%$ & $46.77 \%$ & $100.00 \%$ \\
\hline 23 & $\begin{array}{l}\text { Repair and } \\
\text { installation } \\
\text { of machin- } \\
\text { ery and } \\
\text { equipment }\end{array}$ & $89.38 \%$ & $6.43 \%$ & $0.00 \%$ & $0.00 \%$ & $-0.01 \%$ & $4.20 \%$ & $100.00 \%$ \\
\hline 24 & $\begin{array}{l}\text { Electricity, } \\
\text { gas, steam } \\
\text { and air } \\
\text { condition- } \\
\text { ing supply }\end{array}$ & $65.23 \%$ & $33.69 \%$ & $0.00 \%$ & $0.00 \%$ & $0.54 \%$ & $0.54 \%$ & $100.00 \%$ \\
\hline 25 & $\begin{array}{l}\text { Water collec- } \\
\text { tion, treat- } \\
\text { ment and } \\
\text { supply }\end{array}$ & $79.43 \%$ & $20.49 \%$ & $0.00 \%$ & $0.00 \%$ & $0.09 \%$ & $0.00 \%$ & $100.00 \%$ \\
\hline 26 & $\begin{array}{l}\text { Sewerage; } \\
\text { waste } \\
\text { collection, } \\
\text { treatment } \\
\text { and disposal } \\
\text { activities; } \\
\text { materials } \\
\text { recovery; } \\
\text { remediation } \\
\text { activities } \\
\text { and other } \\
\text { waste man- } \\
\text { agement } \\
\text { services }\end{array}$ & $25.43 \%$ & $73.79 \%$ & $0.00 \%$ & $0.00 \%$ & $0.00 \%$ & $0.78 \%$ & $100.00 \%$ \\
\hline 27 & Construction & $7.05 \%$ & $0.00 \%$ & $0.00 \%$ & $92.98 \%$ & $-0.04 \%$ & $0.00 \%$ & $100.00 \%$ \\
\hline 28 & $\begin{array}{l}\text { Wholesale } \\
\text { and retail } \\
\text { trade and } \\
\text { repair of } \\
\text { motor } \\
\text { vehicles and } \\
\text { motorcycles }\end{array}$ & $35.86 \%$ & $48.76 \%$ & $0.00 \%$ & $9.67 \%$ & $0.00 \%$ & $5.71 \%$ & $100.00 \%$ \\
\hline 29 & $\begin{array}{l}\text { Wholesale } \\
\text { trade, } \\
\text { except } \\
\text { of motor } \\
\text { vehicles and } \\
\text { motorcycles }\end{array}$ & $35.36 \%$ & $49.19 \%$ & $0.00 \%$ & $9.75 \%$ & $0.00 \%$ & $5.70 \%$ & $100.00 \%$ \\
\hline
\end{tabular}




\begin{tabular}{|c|c|c|c|c|c|c|c|c|}
\hline$\#$ & $\begin{array}{l}\text { Sectors } \\
\text { in WIOD }\end{array}$ & $\begin{array}{l}\text { Input } \\
\text { to other } \\
\text { sectors }\end{array}$ & $\begin{array}{l}\text { Household } \\
\text { consumption }\end{array}$ & $\begin{array}{l}\text { Government } \\
\text { consumption }\end{array}$ & $\begin{array}{l}\text { Inputs } \\
\text { for investment }\end{array}$ & $\begin{array}{l}\text { Changes } \\
\text { in stocks }\end{array}$ & Exports & Total \\
\hline 30 & $\begin{array}{l}\text { Retail trade, } \\
\text { except } \\
\text { of motor } \\
\text { vehicles and } \\
\text { motorcycles }\end{array}$ & $35.29 \%$ & $49.24 \%$ & $0.00 \%$ & $9.76 \%$ & $0.00 \%$ & $5.70 \%$ & $100.00 \%$ \\
\hline 31 & $\begin{array}{l}\text { Land trans- } \\
\text { port and } \\
\text { transport via } \\
\text { pipelines }\end{array}$ & $16.04 \%$ & $71.18 \%$ & $0.00 \%$ & $8.80 \%$ & $0.21 \%$ & $3.77 \%$ & $100.00 \%$ \\
\hline 32 & $\begin{array}{l}\text { Water trans- } \\
\text { port }\end{array}$ & $25.32 \%$ & $53.28 \%$ & $0.00 \%$ & $16.00 \%$ & $0.00 \%$ & $5.39 \%$ & $100.00 \%$ \\
\hline 33 & Air transport & $10.79 \%$ & $76.88 \%$ & $0.00 \%$ & $1.98 \%$ & $1.31 \%$ & $9.04 \%$ & $100.00 \%$ \\
\hline 34 & $\begin{array}{l}\text { Warehousing } \\
\text { and support } \\
\text { activities for } \\
\text { transporta- } \\
\text { tion }\end{array}$ & $53.39 \%$ & $38.94 \%$ & $0.00 \%$ & $4.26 \%$ & $0.00 \%$ & $3.41 \%$ & $100.00 \%$ \\
\hline 35 & $\begin{array}{l}\text { Postal and } \\
\text { courier } \\
\text { activities }\end{array}$ & $69.51 \%$ & $30.46 \%$ & $0.00 \%$ & $0.00 \%$ & $0.03 \%$ & $0.00 \%$ & $100.00 \%$ \\
\hline 36 & $\begin{array}{l}\text { Accommoda- } \\
\text { tion and } \\
\text { food service } \\
\text { activities }\end{array}$ & $16.60 \%$ & $83.40 \%$ & $0.00 \%$ & $0.00 \%$ & $-0.01 \%$ & $0.00 \%$ & $100.00 \%$ \\
\hline 37 & $\begin{array}{l}\text { Publishing } \\
\text { activities }\end{array}$ & $70.74 \%$ & $29.26 \%$ & $0.00 \%$ & $0.00 \%$ & $0.00 \%$ & $0.00 \%$ & $100.00 \%$ \\
\hline 38 & $\begin{array}{l}\text { Motion } \\
\text { picture, } \\
\text { video and } \\
\text { television } \\
\text { programme } \\
\text { produc- } \\
\text { tion, sound } \\
\text { recording } \\
\text { and music } \\
\text { publishing } \\
\text { activities; } \\
\text { program- } \\
\text { ming and } \\
\text { broadcast- } \\
\text { ing activities }\end{array}$ & $13.01 \%$ & $84.14 \%$ & $0.15 \%$ & $0.62 \%$ & $0.07 \%$ & $2.00 \%$ & $100.00 \%$ \\
\hline 39 & $\begin{array}{l}\text { Telecommuni- } \\
\text { cations }\end{array}$ & $34.70 \%$ & $64.68 \%$ & $0.00 \%$ & $0.00 \%$ & $-0.07 \%$ & $0.69 \%$ & $100.00 \%$ \\
\hline 40 & $\begin{array}{l}\text { Computer } \\
\text { program- } \\
\text { ming, } \\
\text { consultancy } \\
\text { and related } \\
\text { activities; } \\
\text { informa- } \\
\text { tion service } \\
\text { activities }\end{array}$ & $53.79 \%$ & $3.72 \%$ & $0.00 \%$ & $41.54 \%$ & $0.00 \%$ & $0.95 \%$ & $100.00 \%$ \\
\hline 41 & $\begin{array}{l}\text { Financial ser- } \\
\text { vice activi- } \\
\text { ties, except } \\
\text { insurance } \\
\text { and pension } \\
\text { funding }\end{array}$ & $38.36 \%$ & $61.15 \%$ & $0.54 \%$ & $0.00 \%$ & $-0.11 \%$ & $0.06 \%$ & $100.00 \%$ \\
\hline
\end{tabular}




\begin{tabular}{|c|c|c|c|c|c|c|c|c|}
\hline$\#$ & $\begin{array}{l}\text { Sectors } \\
\text { in WIOD }\end{array}$ & $\begin{array}{l}\text { Input } \\
\text { to other } \\
\text { sectors }\end{array}$ & $\begin{array}{l}\text { Household } \\
\text { consumption }\end{array}$ & $\begin{array}{l}\text { Government } \\
\text { consumption }\end{array}$ & $\begin{array}{l}\text { Inputs } \\
\text { for investment }\end{array}$ & $\begin{array}{l}\text { Changes } \\
\text { in stocks }\end{array}$ & Exports & Total \\
\hline 42 & $\begin{array}{l}\text { Insurance, } \\
\text { reinsurance } \\
\text { and pension } \\
\text { funding, } \\
\text { except } \\
\text { compul- } \\
\text { sory social } \\
\text { security }\end{array}$ & $16.51 \%$ & $70.72 \%$ & $0.00 \%$ & $0.00 \%$ & $1.90 \%$ & $10.88 \%$ & $100.00 \%$ \\
\hline 43 & $\begin{array}{l}\text { Activities } \\
\text { auxiliary to } \\
\text { financial } \\
\text { services and } \\
\text { insurance } \\
\text { activities }\end{array}$ & $55.86 \%$ & $44.14 \%$ & $0.00 \%$ & $0.00 \%$ & $0.00 \%$ & $0.00 \%$ & $100.00 \%$ \\
\hline 44 & $\begin{array}{r}\text { Real estate } \\
\text { activities }\end{array}$ & \#N/D & \#N/D & \#N/D & \#N/D & \#N/D & \#N/D & \#N/D \\
\hline 45 & $\begin{array}{l}\text { Legal and } \\
\text { accounting } \\
\text { activities; } \\
\text { activities of } \\
\text { head offices; } \\
\text { manage- } \\
\text { ment } \\
\text { consultancy } \\
\text { activities }\end{array}$ & $73.44 \%$ & $13.25 \%$ & $0.00 \%$ & $13.33 \%$ & $-0.02 \%$ & $0.00 \%$ & $100.00 \%$ \\
\hline 46 & $\begin{array}{l}\text { Architec- } \\
\text { tural and } \\
\text { engineering } \\
\text { activities; } \\
\text { technical } \\
\text { testing and } \\
\text { analysis }\end{array}$ & $89.21 \%$ & $10.58 \%$ & $0.00 \%$ & $0.00 \%$ & $-0.01 \%$ & $0.22 \%$ & $100.00 \%$ \\
\hline 47 & $\begin{array}{l}\text { Scientific } \\
\text { research } \\
\text { and devel- } \\
\text { opment }\end{array}$ & $82.77 \%$ & $0.00 \%$ & $16.16 \%$ & $0.62 \%$ & $0.05 \%$ & $0.40 \%$ & $100.00 \%$ \\
\hline 48 & $\begin{array}{l}\text { Advertising } \\
\text { and market } \\
\text { research }\end{array}$ & \#N/D & \#N/D & \#N/D & \#N/D & \#N/D & \#N/D & \#N/D \\
\hline 49 & $\begin{array}{l}\text { Other profes- } \\
\text { sional, } \\
\text { scientific } \\
\text { and techni- } \\
\text { cal activities; } \\
\text { veterinary } \\
\text { activities }\end{array}$ & $86.77 \%$ & $9.41 \%$ & $0.00 \%$ & $0.00 \%$ & $-2.22 \%$ & $6.04 \%$ & $100.00 \%$ \\
\hline 50 & $\begin{array}{l}\text { Administrative } \\
\text { and support } \\
\text { service } \\
\text { activities }\end{array}$ & $37.58 \%$ & $62.09 \%$ & $0.36 \%$ & $0.00 \%$ & $-0.06 \%$ & $0.03 \%$ & $100.00 \%$ \\
\hline 51 & $\begin{array}{l}\text { Public admin- } \\
\text { istration and } \\
\text { defence; } \\
\text { compul- } \\
\text { sory social } \\
\text { security }\end{array}$ & $0.04 \%$ & $0.29 \%$ & $99.51 \%$ & $0.00 \%$ & $0.17 \%$ & $0.00 \%$ & $100.00 \%$ \\
\hline 52 & Education & $0.52 \%$ & $22.82 \%$ & $76.65 \%$ & $0.00 \%$ & $0.00 \%$ & $0.00 \%$ & $100.00 \%$ \\
\hline 53 & $\begin{array}{l}\text { Human health } \\
\text { and social } \\
\text { work activi- } \\
\text { ties }\end{array}$ & $0.00 \%$ & $32.83 \%$ & $67.26 \%$ & $0.00 \%$ & $-0.09 \%$ & $0.00 \%$ & $100.00 \%$ \\
\hline
\end{tabular}




\begin{tabular}{llllllll}
\hline$\# \quad \begin{array}{l}\text { Sectors } \\
\text { in WIOD }\end{array}$ & $\begin{array}{l}\text { Input } \\
\text { to other } \\
\text { sectors }\end{array}$ & $\begin{array}{l}\text { Household } \\
\text { consumption }\end{array}$ & $\begin{array}{l}\text { Government } \\
\text { consumption }\end{array}$ & $\begin{array}{l}\text { Inputs } \\
\text { for investment }\end{array}$ & $\begin{array}{l}\text { Changes } \\
\text { in stocks }\end{array}$ & Exports & Total \\
\hline $54 \begin{array}{c}\text { Other service } \\
\text { activities }\end{array}$ & $8.32 \%$ & $89.18 \%$ & $2.38 \%$ & $0.00 \%$ & $0.00 \%$ & $0.11 \%$ & $100.00 \%$ \\
$55 \begin{array}{l}\text { Activities of } \\
\text { households } \\
\text { as employ- } \\
\text { ers; undif- } \\
\text { ferentiated } \\
\text { goods- and } \\
\text { services- } \\
\text { producing } \\
\text { activities of } \\
\text { households } \\
\text { for own use }\end{array}$ & $100.00 \%$ & $0.00 \%$ & $0.00 \%$ & $0.00 \%$ & $0.00 \%$ & $100.00 \%$ \\
$56 \begin{array}{l}\text { Activities of } \\
\text { extraterrito- } \\
\text { rial organi- } \\
\text { zations and } \\
\text { bodies }\end{array}$ & & & & & & & \\
\hline
\end{tabular}

Received: 27 July 2018 Revised: 9 January 2019 Accepted: 11 June 2019

Published online: 22 June 2019

\section{References}

Amiti M, Konings J (2007) Trade liberalization, intermediate inputs, and productivity: evidence from Indonesia. Am Econ Rev 97(5):1611-1638

Araujo R (2012) New insights from a structural economic dynamic approach to balance of payment constrained growth. In: Soukiazis E, Cerqueira P (eds) Models of balance of payments constrained growth: history, theory and empirical evidence. Palgrave MacMillan, London, pp 217-238

Araujo R, Lima G (2007) A structural economic dynamic approach to balance of payment constrained growth. Camb J Econ 31(5):755-774

Araujo R, Teixeira J (2004) A Pasinettian approach to international economic relations: the pure labour case. Rev Political Econ 16(1):117-129

Atesoglu H (1993) Balance-of-payments-constrained growth. J Post Keynes Econ 15(4):507-516

Blecker R, Ibarra C (2013) Trade liberalization and the balance of payments constraint with intermediate imports: the case of Mexico revisited. Struct Change Econ Dyn 25(C):33-47

Goldberg PK, Khandelwal A, Pavcnik N, Topalova P (2010) Imported intermediate inputs and domestic product growth: evidence from India. Q J Econ 125(4):1727-1767

Gouvea R, Lima G (2010) Structural change, balance-of-payments constraint, and economic growth: evidence from the multisectoral Thirlwall's law. J Post Keynes Econ 33:171-206

Gouvea R, Lima G (2013) Balance-of-payments-constrained growth in a multisectoral framework: a panel data investigation. J Econ Stud 40(2):240-254

Halicioglu F (2012) Balance-of-payments-constrained growth: the case of Turkey. J Post Keynes Econ 35(1):65-77

Ibarra C (2011) A note on intermediate imports and the BPCG model in Mexico. Econ Change Restruct 44:357-368

Ibarra C, Blecker R (2016) Structural change, the real exchange rate, and the balance of payments in Mexico, 1960-2012. Camb J Econ 40(2):507-539

Jeon Y (2009) Balance-of-payment constrained growth: the case of China, 1979-2002. Int Rev Appl Econ 23(2):135-146

Johansen S (2001) Likelihood analysis of the I(2) model. Scand J Stat 24(4):433-462

Johansen S, Juselius K (1990) Maximum likelihood estimation and inference on cointegration with application to the demand for money. Oxf Bull Econ Stat 52:169-210

McGregor PG, Swales JK (1985) Professor Thirlwall and balance of payments constrained growth. Appl Econ 17(1):17-32

McMillan M, Rodrik D (2011) Globalization, structural change and productivity growth. Working paper 17143, Cambridge, MA, June 2011

Missio F, Araujo R, Jayme F Jr (2017) Endogenous elasticities and the impact of the real exchange rate on structural economic dynamics. Struct Change Econ Dyn 42:67-75

Moreno-Brid J (1999) Mexico's economic growth and the balance of payments constraint: a cointegration analysis. Int Rev Appl Econ 13(2):149-159

Moreno-Brid J (2002) Liberalización Comercial y la Demanda de Importaciones en México. Investig Económ 62(240):13-50

Moreno-Brid J, Santamaría J, Rivas J (2005) Industrialization and economic growth in Mexico after NAFTA: the road travelled. Dev Change 36(6):1095-1119

Nishi H (2016) A multi-sectoral balance-of-payments-constrained growth model with sectoral heterogeneity: international competition, productivity dynamics, and economic growth. Struct Change Econ Dyn 39:31-45 
Pacheco-López P, Thirlwall A (2004) Trade liberalisation in Mexico: rhetoric and reality. Banca Nazionale del Lavoro Q Rev 57(229):141-167

Pasinetti L (1981) Structural change and economic growth — a theoretical essay on the dynamics of the wealth of the nations. Cambridge University Press, Cambridge

Pasinetti L (1993) Structural economic dynamics: a theory of the economic consequences of human learning. Cambridge University Press, Cambridge

Perraton J (2003) Balance of payments constrained growth and developing countries: an examination of Thirlwall's hypothesis. Int Rev Appl Econ 17(1):1-22

Razmi A (2005) Balance of payments constrained growth model: the case of India. J Post Keynes Econ 27(4):655-687

Romero J, McCombie J (2016) The multi-sectoral Thirlwall's law: evidence from 14 developed European countries using product-level data. Int Rev Appl Econ 30(3):301-325

Tharnpanich N, McCombie J (2013) Balance-of-payments constrained growth, structural change, and the Thai economy. J Post Keynes Econ 35(4):569-597

Thirlwall A (1979) The balance of payments constraint as an explanation of international growth rates differences. Banca Nazionale del Lavoro Q Rev 31(128):45-53

Thirlwall A (2012) Balance of payments constrained growth models: history and overview. In: Soukiazis E, Cerqueira P (eds) Models of balance of payments constrained growth: history, theory and empirical evidence. Palgrave MacMillan, London, pp 11-49

Thirlwall A (2013) Economic growth in an open developing economy: the role of structure and demand. Edward Elgar, Cheltenham

\section{Publisher's Note}

Springer Nature remains neutral with regard to jurisdictional claims in published maps and institutional affiliations.

\section{Submit your manuscript to a SpringerOpen ${ }^{\circ}$ journal and benefit from:}

- Convenient online submission

- Rigorous peer review

- Open access: articles freely available online

- High visibility within the field

Retaining the copyright to your article

Submit your next manuscript at $\gg$ springeropen.com 